\title{
The Concept of Materials in Historical Perspective
}

\author{
Bernadette Bensaude-Vincent
}

Das Konzept von Werkstoffen in historischer Perspektive

In diesem Beitrag lege ich dar, dass in der zweiten Hälfte des 20. Jahrhunderts das Konzept von Werkstoffen (materials) als charakteristischer ontologischer Typus eines neuen Forschungs- und Wissenschaftsstils aufkam. Das soll nicht heißen, dass Werkstoffe niemals zuvor wissenschaftlich bearbeitet worden wären. Zweifellos hatten sich zahlreiche wissenschaftliche Disziplinen mit den Eigenschaften einer ganzen Reihe von Werkstoffen befasst. Doch wurden dabei Werkstoffe nicht als generische, also alle Arten von Stoffen umfassende, Entität betrachtet.

Ziel dieses Aufsatzes ist zu verstehen, wie Werkstoffe als Gattungseinheit entstanden sind und zu Objekten einer Wissenschaft wurden, die so unterschiedliche Dinge wie Papier, Holz, Metalle, Beton, Keramik, Polymere, Halbleiter und Kohlenstoff-Nanoröhren umfasst. Im Bemühen, die historischen Begleitumstände des Auftretens von Werkstoffen zu bestimmen, werde ich diese zunächst in historischer und ontologischer Hinsicht einordnen. Wie war es möglich, all diese Dinge in einer einzigen Gattung zu vereinigen? Dann wende ich mich dem sich verändernden Status von Werkstoffen zu, ein Resultat der erfolgreichen Materialforschung. Werkstoffe sind nicht länger die Vorbedingungen, die dem Entwurfsprozess Beschränkungen auferlegen, sondern werden nun selbst spezifisch entworfen. Solche materials by design sind echte, individuell zugeschnittene schöpfungen und nicht nur einfach Handelsprodukte. Zudem birgt der Wandel ihres ontologischer Status ein Paradox mit seiner Tendenz zur Entmaterialisierung von Technik.

Schlüsse/wörter: Chemie, Materialforschung, Design, Entmaterialisierung, 20. Jahrhundert

Keywords: Chemistry, Materials Science and Engineering, design, dematerialization, $20^{\text {th }}$ century

Materials science courses and meetings in the 1980s vehemently urged students and engineers to adopt a "materials way of thinking". The injunction was meant to spread an alternative style of engineering. Materials should no longer be considered as the first step in an engineering project or as the precondition for designing a piece of artefact. The engineering project included the choice or the design of a specific material, which in turn opened up new opportunities for the design of the end product. In a nutshell, the materials way of thinking required a systems approach, that is, the relinquishment of the linear model of innovation (Nye 2006). 
The phrase "materials thinking" provides a useful guideline for capturing the specificity of materials science and its underlying ontological commitments. The notion of "styles of thinking" in science introduced by the historian of science Alistair Crombie encompasses not only a collective way of thinking but also a specific experience of nature, which determines the research pathways and the questions to be addressed. ${ }^{1}$ Crombie thus distinguished six different styles of thinking in European science - 1) postulation, 2) experimental argument, 3) hypothetical modelling, 4) taxonomy logic, 5) probabilistic and statistical analysis, 6) historical derivation - and insisted on the pluralism of rationalities.

Ian Hacking took up Crombie's notion of style in order to understand how new objects and new categories came into being and endured in the history of science. Styles of reasoning are contingent historical matters shaped through social negotiations and yet they transcend historical circumstances as they provide canons of truth and create new objects. The notion of style of reasoning thus led Hacking to a "historical ontology".

Every style of reasoning introduces new types of objects, evidence, sentences ways of being a candidate for truth or falsehood laws or at any rate modalities, possibilities. We should not envisage first the style and then the novelties. The style comes into being with the instances, the recognition of something as new solidifies the style after it begun. (Hacking 2002: 189).

In this paper I argue that materials emerged in the second half of the twentieth century as characteristic ontological creatures of a new style of reasoning, based on the design of individual material entities for performing specific functions. That does not imply that materials have never been under scientific scrutiny prior to this period. Certainly a variety of disciplines had focused on the properties of a number of materials. Materials nonetheless were not dealt with as a generic entity encompassing all "families" of materials. The purpose of this paper is to understand how materials came into being as a generic entity, as a science object per se. I will first attempt to identify the historical circumstances of the emergence of materials as a genre. Then I will examine the changing ontological status of individual materials, which resulted from the success of materials science and engineering. A material is no longer a prerequisite imposing constraints on the process of design, but is designed as such for specific performances. Such materials by design are true individual creations rather than simple commodities. And their changing ontological status raises a paradox as it encourages a tendency to dematerialize technology.

\section{An Eclectic Genre}

Strictly speaking a generic concept of materials is an oxymoron. At first glance a collection of stuffs as dissimilar as paper, wood, metals, concrete, ceramics, polymers, semi-conductors, or carbon nanotubes looks like a surrealist 
classification à la Borges. How was it possible to gather all those items in a single genre? The construction of a genre implies at least two "styles of thought": abstract reasoning and analogy reasoning (to identify a common feature beyond individual features).

\section{Matter versus Materials}

Matter is a generic and abstract notion forged throughout a long history, whereas the notion of material refers to singular entities. The two terms 'matter' and 'material' stem from the same Latin substantive materies, from the root mater (mother) that conveys the idea of a creative and feminine power. As the French sociologist Marcel Mauss stated, originally materies referred to wood, more precisely to the core of the tree-trunk (matrix). This part presenting long regular fibres, was the most suitable for carpentry.

In effect, materies belonged to the vocabulary of loggers and carpenters. It referred to the core of the tree. It was wood, the essence of every thing: a solid expression which connoted life. It also was the thread for making the eft of a fabric. It is the veined block of marble out of which the sculptor following the vein will give birth to the statue. (Mauss 1945: 16, translation by author ${ }^{2}$ )

Wood is the archetype of both matter and material. However the concept of material lacks the objectivity of matter since materials are varieties of matter viewed as useful for human purposes. Materials were objects of selection, namely a selection of substances occurring in nature. For instance in the old days when shipbuilding for the merchant marine was a central activity, Dutch shipwrights used to make long journeys to visit pine woods in a specific area of Southern France in order to select the most suitable tree for the mast of the ship to build. Trees were extracted from nature, separated from their natural environment and became wood in relation to the design of a specific artefact. Thus the substantive 'material' combines phusis and technê, it is a hybrid notion referring to an alliance between natural beings and man's needs, which has been used as the distinctive mark of various ages of human civilizations: Stone Age, Bronze Age, Iron Age and so on.

The Latin etymology of the term material suggests a gradual semantic shift from the reference to a definite part of a tree, object of choice for a specific technological purpose to wood in general; then from wood to all materials employed in human arts; and finally from craftsmen's materials to the substance of all bodies in general. The modern concept of matter appears as the result of a process leading from a singular entity to a more general and more abstract notion. The notion of material seems more archaic, more primitive than matter because it lacks abstraction and generality.

According to the old scholastic dictum that "there is no science but of the general", there should be no science of materials. In standard history the emergence of modern science is described as a process towards more and more abstraction. It looks like the result of a long-term strategy to go beyond the 
multiple and individual materials. The Aristotelian notion of "substance" that is common to all natural and artificial bodies was deprived from its individual or secondary qualities and reduced to its geometrical extension by Descartes and Robert Boyle's natural philosophy. Modern physics was built upon the notion of a 'catholic matter'. It thus seems that Western science had to give up the study of materials in order to become a rational and mathematical science.

The construction of an abstract and generic concept of matter conditioned the science of nature in general. Without the idea of something common to the infinite variety of concrete individual bodies; without the assumption that something is conserved through movements as well as through chemical transformations there would be no physics. As Émile Meyerson argued, identity and conservation principles are the essence of any rational thinking (Meyerson 1908). Moving beyond the multiplicity and the variety of individual and phenomenological substances was the key to 'modern science' . It enabled natural philosophers to formulate laws of nature. Natural laws - even the only approximate ones - are universally valid statements. They apply to the behaviour and properties of all entities, in all situations, without exception. In Gaston Bachelard's terms, the notion of materials being linked to concrete, sensory qualities, and to human interests can be considered as a typical epistemological obstacle that modern science had to overcome (Bachelard 1938).

\section{In the Jungle of Chemicals}

As Gabriel-François Venel noted in the entry "Principes" of Diderot's Encyclopédie, "no natural body consists of matter per se" (Venel 1765). Rather than being concerned with matter in general, chemists wanted to know why only one particular acid dissolves gold or why spirit of nitre joined to salt of tartar produces true saltpetre. As they paid attention to individual properties, they were confronted with a jungle of different materials and their rapports or affinities. Chemistry involved innumerable descriptions, comparisons and attempts at classification of individual substances, so that it was a kind of 'zoology' of materials. However most of laboratory work consisted of purifying and reacting natural substances in order to understand their composition and mutual affinities. In this respect Ursula Klein and Wolfgang Lefevre were right to point out that chemists were not dealing with "natural raw materials but materials processed in the arts and crafts" (Klein/Lefevre 2007: 302). Yet the use of the term 'materials' for referring to eighteenth-century chemicals is an anachronism since chemists used the generic terms 'substances' or 'bodies' to refer to their chemicals. While this anachronism is appropriate to emphasize the role of craftsmen in early modern chemistry it nevertheless overlooks the continuous efforts to gain an objective knowledge of the composition of those substances and to detach them not only from their natural origin but from their technological uses as well (Bensaude-Vincent 1993). The reform of the 
chemical language in 1787 can be seen as the outcome of such long-term efforts since the new language banned denominations referring to local geographical origins or medical uses of substances in favour of denominations mirroring their intrinsic compositions. The vocabulary coined by generations of artisan chemists was replaced by systematic names referring to the nature and proportion of elements in the compound. With the new nomenclature individual substances became commensurable samples of chemically composed matter. Their commensurability was grounded on a systematic use of the balance governed by the principle of conservation of matter (BensaudeVincent 1993). In using this old principle Lavoisier focused on the quantity of matter that entered and left the reactional space, and was able to introduce an algebraic equation between inputs and outputs. Thus modern chemistry developed a specific way of dealing with individual substances that transcends their singularities in making them samples of pure chemical species. Since the nineteenth century the definition of chemical compounds not only requires the elemental composition as expressed in the condensed formulas (for instance $\mathrm{CH}_{4}$ ) but their molecular architecture expressed by their structural formulas. The development of chemical synthesis and the production of thousands of synthetic chemicals over the twentieth century only reinforced the conceptual shift from singularities to peculiarities. As pointed out by the French philosopher Gilles Deleuze, the particular being - the counterpart of the general - can always be replaced or substituted whereas a singular being is unique, it cannot be replaced or substituted, it can merely be copied or mimicked (Deleuze 1969: 8-9).

\section{On the Fringes of Mathematical Physics}

Just as chemists were struggling with the peculiar behaviour of individual substances, Galileo was struggling with the different properties that one and the same material could present according to its size. In his dialog on Two New Sciences, Galileo clearly circumscribed the obstacles that wooden structures raised for mathematizing natural philosophy. Thanks to frequent visits at the Arsenal in Venice, Galileo/Salviati and his interlocutor Sagredo were familiar with engineering problems. The 'master' workers knew by experience that they could not apply the same rules and use the same devices for building small ships and big ships. The natural philosopher eager to apply geometry to all solids was tempted to consider this opinion as a popular prejudice since the properties of geometrical figures - the circle, the cone, or the pyramid - are independent from their sizes. Consequently solids should retain their properties whatever their spatial dimensions. Similar shapes should present similar behaviour. However that is obviously not the case with materials. Standard geometrical reasoning does not apply to a wooden piece because the strength of a material structure is size-sensitive. Sometimes big structures are more successful (for instance in the case of a pendulum), then again small structures 
are more successful. There is no proportionality between the quantity of matter and the strength of the material structure. Enlarging the size of a material structure affects its mechanical properties.

Sagredo remarked that in this case it would be impossible to find two wooden sticks, made of the same wood which shall be alike in strength and resistance but unlike in size. And Galileo confirmed that not only materials are unique, but for each material structure there is an optimal dimension that allows it to maintain itself: "[N]ature cannot produce a horse as large as twenty ordinary horses or a giant ten times taller than an ordinary man". (Galileo 1638, First Day: 4). Galileo emphasized that nature's material structures are characterized by a kind of mutual adaptation between their size and the stuff they are made of.

This assumption did not prevent Galileo from initiating a "new science", a science where two different poles made of the same wood could crack or resist stress. The discussion in the Arsenal on the First Day was only meant to show that a naive (but apparently plausible) geometrical reasoning could not be applied to materials. It was a preliminary step to clear the way for Galileo's presentation on the Second Day. Galileo stated rules of proportionality with a proportionality constant that enabled engineers to determine and predict the strength of a wooden structure according to its size. ${ }^{3}$ But Galileo did not venture into comparisons between materials. He cautiously confined himself to comparing beams of different sizes for the same material. He could not make a meaningful comparison between a steel pole and one made of wood. In his "new science" trying to cope with size-sensitive properties there was no place for ceteris paribus generalizations.

\section{Between Ideal and Impure Structures}

If the conceptual gap between materials and matter measures the distance between qualitative physics and modern, mathematical physics; if it demarcates a knowledge based on rules or algorithms for engineers and architects from a rational science based on universal laws, how will it be possible to create a science of materials without going back to pre-modern physics or without considering the singularity of materials as defects or imperfections of ideal matter? By forging a generic notion of material - there is no alternative. However, a generic materials perspective is nothing easy to construct. There are two major difficulties.

First, in its broadest interpretation the notion of materials may refer to species such as wood, paper, metal or glass. But the plural to the term 'materials' presupposes the construction of a genre that includes such diverse species of materials as pure silicon and cement, paper and fullerenes, wood and liquid crystals. How to make a genre out of such heterogeneous things? How to construct a materials science that would not eventually tend towards a science of matter, be it physics or chemistry? 
Second, the difficulty is even deeper because a material is not only particular, but actually singular and strictly speaking unique. A particular material can be subsumed under a generic notion. But a singular unique material can only be defined by its distance from the genus. Is it possible to deal with singular material structures without defining them as impure or deficient structures?

Continuum mechanics developed by Euler and Bernoulli in the $18^{\text {th }}$ century, and by Cauchy, Poisson, Navier in the 19th century was an interesting attempt. Materials were treated as pure deformable continua, endowed with mass and mechanical properties (for instance, shear modulus and compressibility). As a result, materials became "perfect" structures that grouped themselves into classes (for instance, elastic solids, viscous fluids) according to their response to an applied force. In this perspective, the only difference between different objects is the numerical values of their material properties. And this in turn permitted the establishment of a science of materials that was theoretically just as mathematical and predictive as Newtonian mechanics for a given class of materials. Yet the equations worked only for ideal materials, and were applicable only to their mechanical properties. Continuum mechanics thus emphasized the persistent gap between ideal and real-world systems.

In the eighteenth and nineteenth centuries the scientists' attention was mainly focused on mechanical properties such as elasticity. Most efforts were aimed at drawing mathematical models of the mechanical behaviour of materials. The famous historian of metallurgy Cyril Stanley Smith emphasized the significance and the limits of this approach to materials (Smith 1981). The focus on mathematical models prevented nineteenth century engineers like Charles Navier and others from taking into account the chemists' contributions to the study of metals. Because they only considered problems susceptible to mathematical solutions, scientists and engineers did not pay attention to the properties of crystals. In particular the contribution of early nineteenth-century chemists went unnoticed (Smith 1962).

Moreover it should be emphasized that this mathematical science of materials was based on one single class of materials. As the French historian of technology André Guillerme pointed out, each class of materials offers both constraints and potentialities for the construction of materials science according to the intrinsic nature of a given material (Guillerme 1994: 231). As long as wood remained the most common material used in ship and house building the science of materials was restricted to Galileo's attempt because of the complexity of wood structure. By contrast, iron and steel offer a number of specific characters. Not only iron is a passive material that can be melted, moulded, cut, pressed, stamped, and welded, it can also be hardened by addition of carbon or thermal treatments. "Iron does not work by itself; it is put to work." (ibid.: 233) Unlike wood, it is a homogeneous and isotropic material 
that allows mathematical treatment with differential equations. Iron thus became a model material and a driving force for promoting applied sciences. "For physicists, iron was with regard to solids what water was with regard to fluids: it tested the most advanced mathematical theories at the time applied sciences were emerging in France and England." (Ibid.)

It is only because iron worked as a kind of 'perfect' material that it allowed a mathematical treatment. As long as scientists and engineers ignored the small-scale structure of metals they could treat them as pure deformable continua. How to deal with materials without dissociating the real material from an ideal structure? The key(word) to that is relations. Materials are a relational entity.

\section{Coupling Structure and Properties}

Historically materials science and engineering came neither out of chemistry, nor out of the part of mechanics studying the strength of materials. It accrued from metallurgy when the science of metals was deeply transformed by the access to the microstructure of metals X-ray diffraction allowed. For instance, Robert Cahn, who pioneered materials science in Great Britain, described its emergence as the result of the changes that solid-state physics brought about in metallurgy (Smith 1959, Cahn 2001). The determination of microstructure became the prime concern of physical metallurgy and the notions of crystal lattices, of dislocation, of defect, provided a key for understanding the macroscopic properties of metals. The connection between microstructure and mechanical properties was thus probed and the models and theories elaborated by physicists were put at work for designing new materials (Hoddeson/ Braun/Teichman/Weart 1992). Quantum mechanics later provided the theoretical foundations for understanding the microscopic pictures of solids. Solid state became an object of investigation in itself. Solid-state physicists discriminated between the properties depending on the idealized crystal pattern and the properties dependent on 'accidents' of the inner arrangement or of the surface of the solid. The focus on structure-sensitive properties in the study of crystals has been identified as the main route leading to materials science (Weart 1992: 623). This claim rests on the evidence that metallurgy departments in a number of academic institutions were renamed "metallurgy and materials science" around 1960 and a few years later materials science became autonomous entities.

Although metallurgy acted as a nucleus for growing materials science after being deeply transformed by the emergence of solid-state physics, metals were by no means the unique carriers of the materials generic perspective. Similar changes occurred in field of ceramics in the 1950s. Ceramists who generally had a background in chemistry transformed a knowledge mainly based on empirical practices into a firm basic understanding of the properties. More broadly there is a consensus among the scientists who participated in the 
emergence of materials science around the idea that the changes that occurred in physics in the mid-twentieth century gave the impetus toward a generic perspective on materials transcending the institutional units dealing with traditional families of materials such as glass, ceramics, metals. The emergence of a generic concept of materials would thus instantiate a general trend towards more fundamental and more abstract knowledge. However, presenting materials science as the expression of a supposedly natural tendency to replace empirical practices by science-based technologies gives a partial and biased account of the historical emergence of this 'new science'.

\section{Adding Function and Process}

On the one hand, solid-state physics developed a style of thinking quite different from 'fundamental physics' and has long been considered as 'dirty physics' in contrast to particle physics, for instance. On the other hand, the study of the solid state was only a first step towards the emergence of the generic concept of materials. A solid is not a material. More precisely: solidstate physics provided the notions of microstructure and of structure-sensitive properties. But the relation between structure and properties is only one aspect: the notion of a material requires that structure and properties be coupled with functions or performance. It is only with respect to functionalities that one can gather under the same umbrella such dissimilar stuffs as wood, concrete, paper, polymers, metals, semi-conductors, and ceramics. The generic concept of materials encompassing such dissimilar stuffs presupposes that they share a common feature: they are all materials for...

The commensurability between such dissimilar materials is based on a functional equivalence for specific uses. To perform a specific task one material can be substituted for another one: for instance wood can be replaced by concrete or metal for building construction; wood has been replaced by metal and later on by composites for making skis, and so on. Since materials involve a reference to functionalities and uses there is a fierce competition between them on the market. And the competition between candidates for one application contributes to the consistence of the field of materials science.

The plural entity 'materials' first appeared in the language of science policy makers, under the auspices of a bottleneck for advances in space and military technologies (Bensaude-Vincent 2001). In 1957, when the response to Sputnik encouraged heavy investments in ambitious space programs, the President Eisenhower's Science Advisory Committee prioritarily singled out materials in general. The idea that all materials and not just rubber or aluminium were strategic emerged in the context of the Cold War as a means for building up sufficient industrial capacity for future emergencies. Through its Advanced Research Project Agency (ARPA), the Department of Defense (DoD) developed contracts with a number of universities for developing new materials fitted for space engines. The program included generous funding of university 
research with the intention of military exploitation, and strongly encouraged interdisciplinarity through corresponding labs modelled after the nuclear and electronics labs. The interdisciplinary labs (IDL) represented the exportation of the corporate laboratory's way of doing research into the universities.

Thus the emergence of the generic concept of materials resulted as much from a smooth disciplinary evolution toward science-based technologies as from military and political pressures in a specific national context of the USA in the period of the Cold War. However in the 1970s priorities changed with the oil crisis and military budget cuts. Materials research was reoriented towards the growing concern with renewable resources, environment and economic competition. Environmental and safety legislations put new demands on material scientists. In both, industrialized and developing countries, the overemphasis on basic science compared with the technological needs of materials supply and demand was criticised. Hence it gave cause to repeated complaints about the alleged divorce between university and industry. After a wave of emphasis on fundamental aspects in the 1950s and 1960s, which wiped away the empirical approaches of the past, a new wave came which praised engineering skills. The emphasis was on coupling materials science and engineering and to continue the tradition of mixed science, later renamed applied science. In fact materials science questions the latter notion, presuming a linear sequence from pure science to technological applications. To be more precise materials research was initiated in the context of industrial research aimed at innovation on a competitive market, which developed in the early twentieth century in industrial sites such as BASF or Siemens in Germany or the Bell Labs in the USA. The materials generic perspective is not just the result of an alleged trend toward science-based technology; it is also driven by a general strategy of minimizing risk and cost and by a need for control of all aspects of the business. The so-called vertical integration (Chandler 1977), involved on the one hand a retrograde expansion towards the sources of their raw materials and on the other one looking forward to the end customer. This new design approach has been visualized with the help of a tetrahedron indicating the interaction between four variables: structure, properties, performances and process - for the purpose of materials teaching. ${ }^{5}$

To sum up this section: rather than a theoretical notion the generic entity of materials emerged as a social construction. It resulted from a close cooperation between governmental initiatives prompted by the Cold War, universities and industrial companies. Prevailing in the 1980s it was a characteristic style of thinking with a focus on processing and performance. Thus a conceptual framework emerged along with new strategies for designing materials. ${ }^{6}$ The generic concept of materials accrued from the interaction between these various actors. It is an abstract notion defined by a set of relations between at least the four parameters ${ }^{7}$ structure, properties, 
performances, process - to which end-users may also be added as a fifth parameter. In this respect, materials are a boundary concept, which helps to create a community of practitioners.

\section{Materials by Design}

In the 1970s, the US National Academy of Science set up a committee to survey materials science and engineering. The report of the COSMAT issued in 1975 raised a puzzling issue prompted by the proliferation of new materials: "The expanding use of a rich diversity of materials is almost extravagant. [...] The rising tide of materials expectation is not for the materials themselves but for things which incorporate materials. Materials themselves are 'junks' and raise the problem of the waste-material processing" (National Research Council 1989: 1-4). This remark may provide a guiding line for examining the ontological status of materials by design. It testifies to the changing status of materials, which used to be a priori constraints for engineering projects and eventually turned into the end product of a design process. It points to a paradox: as materials, they are an end as much as a means; they may become a nuisance rather than a resource for engineers.

\section{The Potentials of Composites}

In order to meet political demands during the Cold War, chemists and materials scientists have designed high-performance materials with a neverseen-before combination of properties for rockets or missiles. Including, for instance, a material combining the light-weight of polymers, and the hightemperature resistance of ceramics with the resilience of metals. This goal has been achieved by developing a new approach, known as "materials by design" (Bensaude-Vincent 1997). Starting from a list of the functions required from a part in a technological system (for instance the wing of this airplane) engineers have to design the best structure combining the set of properties required for performing those functions. The requirements list moves from uses to performances then to properties and finally to structure. Thus function became the priority of the design process while the material itself was the outcome.

The design of high-performance materials heavily relied on the technology of composites. Composite materials are heterogeneous structures made of resin matrix and reinforcing fibre-carbon or kevlar for instance. They were initially modified to extend the field of application of polymers (Mossman/ Morris 1994). However they gradually revealed further potentialities. In contrast to conventional materials having standard specifications and a global market, composites created for aerospace and military applications were developed according to the functional demands of the end product and the 
services expected from the manufactured product. The design of such hightech composite materials for a specific task in a specific environment is unique, providing them with the status of fine pieces of art rather than standard commodities. In addition composite materials are designed in cooperation with customers and suppliers, instead of a linear sequence providing a raw material to be finalized by the customer. The expectation is that the cooperation of various agencies will trigger a synergy between the four variables structure, properties, performance and process - so that the end product will be more than the sum of the two components. The design of a composite material for helicopter rotor blades in the 1970s gives a standard example of such synergistic effects used in materials science textbooks: the substitution of metal for a composite material named Starflex allowed the integration of a dozen small parts into a single flexible structure that formerly had to be processed separately and then assembled. The final piece included a mere 70 instead of 400 to 500 parts (Cognard 1989: 323-330). Thus whereas conventional materials used to be regarded as constraints for engineering artefacts, such materials are providing opportunities for technological innovations. Thanks to their composite structure and to the interactive process of design they are more like a set of potentials than a limitation.

\section{Between Nature and Artefact}

At first glance, nothing is less natural than a composite material combining the properties of metals, ceramics, polymer, to mention just a few. Yet, while materials scientists were struggling to design such uncanny creations, they turned their attention to nature. ${ }^{8}$ They realized that composite materials are rather the rule than the exception in nature. Suddenly they became interested in sea urchins, abalones, dolphins, spiders, and butterflies (Mann/Webb/ Williams 1989).

Against expectation the state-of-the-art products in materials do not stand the test of comparison with the most familiar and modest materials created by nature. Many biomaterials such as wood, bone, and marine shells, presenting complex hierarchical structures and integrating multiple functions are viewed as model materials for technological purposes. Nature ignores the traditional distinction between structural and functional materials, ${ }^{9}$ as well as the boundary between inorganic and organic matter: inorganic and organic components are often coupled in one single structure. Furthermore, they do not need special processes and artificial conditions for their assembly as they self-assemble at ambient temperature.

Hence new materials have been designed challenging the great divide between nature and artefact. Materials scientists either try to mimic natural materials and processes or they directly borrow materials and devices 'invented' by evolution regardless of their specific environment. In the former case, they have taken inspiration from the exquisite structures selected by 
evolution. One of the first successful examples was the creation of a lightweight and resistant material for US Army shields inspired by the laminated microstructure of the abalone, in which there are alternative layers of calcium carbonate and proteins, like bricks and mortar (Sarikaya/Aksay 1995). The iridescent tissue of butterfly wings and the surface of lotus leaves have also inspired functional structures. Biomimetics aims to dispense with the information of the genetic code in order to self-assemble the components and to control the morphogenesis of materials by mobilizing all possible resources from physics, chemistry, and thermodynamics. For instance to obtain molecular recognition and trigger self-assembly they developed supramolecular chemistry, playing with intermolecular bonds instead of making and breaking covalent bonds between atoms. Mimicking nature however does not mean duplicating the original in all its details or faking it, as could be the case with fine art copies. Even when materials scientists mimic marine shells for making strong composites, or lotus leaves for making non-wetting glass, they do not make indistinguishable copies. Similarly, in mimicking processes such as self-assembly in the laboratory they cannot exactly copy the ways of nature, capable of operating at room temperature, in rather messy and aqueous environments as well as in very extreme conditions. Bio-inspired materials have definitely a status of artefacts.

By contrast, materials designed by using the double strands of DNA, for instance, to assemble the parts of electronic circuit at nanoscale have a more hybrid ontological status. They belong to both, the realms of artefacts as well as nature. Of course one can object that such was also the case with traditional materials such as wood, bone, or skin, which have been processed over many centuries to make a variety of artefacts. Still the kind of hybridization initiated by genetic engineering and nanotechnology requires regarding the living cell as a collection of machines operating together. The fashionable phrase 'molecular machine' often used to refer to enzymes, proteins, viruses and bacteria, suggests that living systems are viewed as molecular manufactures. Consequently parts of living systems can be patented and registered to be used as standard parts. Such hybrid structures deeply transform the status of living systems: they are decomposed in a number of elementary units, redefined as functionalities, and abstracted from their own environment; they can be recombined, re-engineered to perform specific tasks in artificial environments. Materials by design thus tend to become the archetype of all materials, regardless of their origin.

\section{A Process of Dematerialization}

Ironically the paradigm of materials by design encourages the process of dematerialization that industrial ecology recommends for a more sustainable development. ${ }^{10}$ The phrase 'materials by design' literally means that materials are man-made rather than simply extracted and processed. However the 
metaphors used for marketing them often connote the view that they are just the concrete result of a human design. For instance in 1995, a semi-product for composite materials manufactured by a French firm was advertised as "grey matter, the raw material for composites". Indeed materials by design are more expensive than conventional materials as they are customized for better performances. However the added value of composite materials is not considered as something the material components as such provide. Rather it derives from the design, from the human project imprinted on them. The term 'smart materials' - sometimes also 'intelligent materials' - became extremely fashionable in the 1990s. It refers to systems including sensors and actuators and capable to respond to signals from either their inner structure or the environment. They are sold as intelligence 'embedded' in matter, as human performances frozen in a material structure.

Matter itself seems to be deprived of determinations. It is valued for being passive, malleable, and plastic just as Plato's chora in the hands of the demiurgos, who shaped the world in the Timeos dialog. It is adaptable to all technological purposes because it is ideally non-resistant. For instance an advertisement for modelling dough manufactured by Menzolit, a company manufacturing semi-products for composites, reads: "What's great about Menzolit's modelling dough is that you can press, inject, and bend them, they suit all your ideas." 11 Thus materials by design revive the technological utopia of emancipation from all material constraints, reminiscent of the philosophical tradition of dualism between matter and spirit. For instance, in 1985, Jean Friedel, executive director of Brochier, advertised his company as aiming "to go beyond the limitations that matter imposes on the most creative aspects of the human mind".

Nanotechnology seems to emerge from the same metaphysical program (Schummer 2010). The nanoinitiatives launched in the 2000s are all based on the assumption that a bottom-up approach designing artefacts at the molecular level 'atom by atom' is much more efficient than the conventional topdown design of artefacts from bulk materials. "Get more from less"- this injunction underlies the so-called Moore's law ${ }^{12}$ that set the pace of innovation in Information and Communication Technology over the past three decades. Nanotechnology extended this imperative to all kinds of technologies, in particular by using nano-structured materials. Such materials are nearly immaterial. On the one hand, the stuff they are made of is reduced to the minimum - a few atoms for instance - and it is no longer the main parameter since their behaviour and their properties basically depend on their surface areas and interfaces. On the other hand, in a number of sectors such as molecular electronics and spintronics, molecules and electrons are turned into 'logical machines,' they become units of information rather than material units. The bulk material no longer matters. Materials are valued as information units or operational units, which just need to be deposited on a material 
surface. Gradually information takes over matter as materials structure are seen as vehicles of information. Thus materials science joins cybernetics and molecular biology in the prevalence of information (Lafontaine 2004).

Hence a "materials way of thinking" developed only recently, which resulted in the improbable construction of a generic notion of materials. Whereas in the paradigm of modern science they have been considered as individual entities raising obstacles to scientific rationality they have been reconfigured in the twentieth century as a generic entity, to be investigated in a multidisciplinary techno-scientific paradigm. In this historical process where science, technology and society are closely intertwined, the ontological status of materials has been deeply reconfigured: they ceased to be considered as prerequisites imposing limits and constraints on engineering projects as they turned into objects of design.

As a result the ontology of materials reveals a striking ambivalence or rather a discrepancy between discourses and actual practices. In the rhetoric of materials research programs and industrial companies the ideal of control over nature and emancipation of the human condition from material constraints is still prevailing, while at the same time, materials are more and more objects of choice, objects of care as indispensable partners of human technological projects.

\section{Acknowledgements}

I want to acknowledge my debt to the anonymous referees who criticized and greatly improved my too sketchy views on Galileo, continuum mechanics, solid-state physics as well as on the issue of genericity.

\section{Endnotes}

1 "A scientific style with its commitments identified certain regularities in the experience of nature, which become the object of inquiry, defined the questions to be put within that subject matter and that style and determined the acceptable answers. A style thus opened certain routes of inquiry and closed others." Crombie 1994, Vol. 1: x-xi. Bensaude-Vincent 2009.

2 French original: "En effet, materies appartenait au vocabulaire du bûcheron et du charpentier. Il désignait le cœur de l'arbre. C'était le bois, essence de toute chose: expression solide qui connotait la vie. C'est aussi le fil qui formera la trame du tissu. C'est le bloc veiné du marbre dont le sculpteur suivant la veine fera naître la statue".

3 Most of Galileo's laws of proportionality remain valid even today. However his assumption about the distribution of tension across the beam where it is attached to the wall was later refined by Mariotte, Bernoulli, and so on.

4 National Materials Advisory Board 1975. See also Abelson/Hammond 1976.

5 See Hentschel 2011 for further analysis of the levels of discipline formation of materials science and engineering (MSE).

6 In this process instruments acted as a driving force. Not only instrumental techniques from x-ray diffraction to STM and AFM - opened the way to microstructures and 
nanostructures, but also they helped create a scientific community. Whatever their different topics, aims and cultures, the users of instrumental facilities meeting in specific buildings embody materials science. In addition, materials scientists do not only present their results in publications but also in patents. They are equally active on the academic stage - writing articles, books and textbooks to promote the field in engineering - and on the industrial stage where they often hold positions in companies or start-ups. In this respect, MSE epitomizes the age of techno-science, as long as this concept means both, that technology is embedded in scientific research as well as that research is oriented towards technological applications.

7 For a parallel between the four parameters and Aristotle's four causes theory see Bensaude-Vincent 1997.

8 For a survey of the changing relations between the nature and synthesis, see Schummer 2003, and Bensaude-Vincent/Newmann 2007.

9 For instance the plasma membrane, which separates the interior of cells from the extracellular matrix is both structural (the phospholipid bi-layer constitutes a sort of cellular exoskeleton) and functional (with proteins exchanging material and energy between the inside and outside of the cell).

10 Industrial Ecology Compendium, http://www.umich.edu/nppcpub/resources/ compendia/ind.ecol.html [last accessed July 2009]

11 Composites, plastiques renforcés fibres de verre textile, No. 8, march/april 1995: 3.

12 In 1965 Gordon Moore, co-founder of Intel, observed that the capacity of semiconductors had doubled every year, since their invention in 1959, and postulated that this exponential growth would continue in the future. His conjecture has been taken as a law, an imperative for semi-conductor industry to grow at this pace.

\section{Literature}

Abelson, Philip H./Allen L. Hammond, eds., 1976. Materials: Renewable and Nonrenewable Resources. American Association for the Advancement of Science.

Bachelard, Gaston, 1938. La Formation de l'esprit scientifique. Paris, Vrin.

Bensaude-Vincent, Bernadette, 1992. The Balance between Chemistry and Politics, The Eighteenth-Century, Essays and Interpretation. 33, 217-237.

Bensaude-Vincent, Bernadette, 1993. Lavoisier. Mémoires d'une révolution. Paris: Flammarion.

Bensaude-Vincent, Bernadette 1997. Eloge du mixte. Matériaux nouveaux et philosophie ancienne. Paris, Hachette Littératures.

Bensaude-Vincent, Bernadette, 2001. The Construction of a Discipline: Materials Science in the U.S.A. Historical Studies in the Physical and Biological Sciences, 31, part 2, 223-248.

Bensaude-Vincent, Bernadette, 2009, The Chemists'Style of Thinking. Berichte zur Wissenschaftsgeschichte, 32, 365-378.

Bensaude-Vincent, Bernadette/Newmann William, eds. 2007. The Natural and the Artificial. An Ever-Evolving Polarity. Cambridge: MIT Press.

Chandler, Alfred D. Jr., 1977. The Visible Hand: The Managerial Revolution in American Business, Cambridge: Harvard University Press.

Cahn, Robert W., 2001. The Coming of Materials Science. Amsterdam, New York, Pergamon.

Cognard, Philippe, 1989. Les applications industrielles des matériaux composites, Paris: Editions du Moniteur.

Crombie, Alistair, 1994. Styles of Scientific Thinking in the European Tradition. London: Gerald Duckworth.

Deleuze, Gilles, 1969. Différence et répétition. Paris: Presses universitaires de France.

Galilei, Galileo, 1638. Two New Sciences, [http://galileoandeinstein.physics.virginia.edu/tns1.htm (last accessed July 2010)].

Guillerme André, 1994. Bâtir la ville. Révolutions industrielles dans les matériaux de construction, France, Grande Bretagne (1760-1840). Paris, Champs-Vallon. 
Hacking, Ian, 2002. Style for historians and philosophers. In: Idem. Historical Ontology. Cambridge, Harvard University Press, 178-199.

Hentschel, Klaus, 2011. Von der Werkstoffforschung zur Materials Science. NTM. Zeitschrift für Geschichte der Wissenschaften, Technik und Medizin, 19, XX-XX.

Hoddeson, Lilian/Ernest Braun/Jürgen Teichman/Spencer Weart, eds. 1992. Out of the Crystal Maze. Chapters from the History of Solid State Physics. Oxford/New York: Oxford University Press.

Klein, Ursula/Lefevre, Wolfgang 2007. Materials in Eighteenth-Century Science. A Historical Ontology. Cambridge: MIT Press.

Lafontaine, Céline, 2004. L'Empire cybernétique. Des machines à penser à la pensée machine.Paris, Seuil.

Mann, Stephen/John Webb/Robert J. P. Williams, eds., 1989. Biomineralization, Chemical and Biological Perspectives.Weinheim, VCH.

Mauss, Marcel, 1945. Conceptions qui ont précédé la notion de matière, In: Item: Onzième semaine de Synthèse, 1939, Qu'est-ce que la matière? Histoire du concept et conceptions actuelles. Paris, Presses universitaires de France.

Meyerson, émile, 1908. Identité et réalité. Paris: Payot [Engl. Transl. Identity and Reality, London: Allen \& Unwin 1930].

Mossman, Susan T.I./Morris Peter J.T., eds., 1994. The Development of Plastics. London: The Science Museum.

National Materials Advisory Board, ed., 1975. Problems and Legislative Opportunities in the Basic Materials Industries. Washington D.C.: National Academy of Sciences.

Nye, David, 2006. From Science to Industry? Flaws in the linear model (Essay review of Karl Grandin, Nina Wormbs and Sven Widmalm, eds. 2005. The Science-Industry Nexus: History, Policy, Implications. Sagamore Beach, Mass.: Science History Publications) Isis, 97, 543-45.

Sarikaya, Mehmet/Ilian Aksay, eds., 1995. Biomimetics: Design and Processing of Materials. Woodbury, AIP Press.

Schummer, Joachim, 2003. The Notion of Nature in Chemistry, Studies in History and Philosophy of Science, 34, 705-736.

Schummer, Joachim, 2010. On the Novelty of Nanotechnology: A Philosophical Essay, In: Anthony Mark Cutter and Bert Gordijn, eds., In Pursuit of Nanoethics. Dordrecht, Springer, in print.

Smith Cyril Stanley, 1959. The development of ideas on the structure of metals. In: Marshall Clagett, ed., Critical Problems in the History of Science. Madison: University of Wisconsin Press, 11-14, 467-498.

Smith Cyril, Stanley, 1962. The Interaction of Science and Practice in the History of Metallurgy, Techology and Culture, 2, 357-67.

Smith Cyril, Stanley 1963.Four Outstanding Researches in Metallurgical History, American Society for Testing and Materials, 1-35.

Smith, Cyril Stanley, 1981. A Search for Structure - Selected Essays on Science, Art, And History. Cambridge: The MIT Press.

Venel, Gabriel-François, 1765. Principes, In: Diderot Denis and D'Alembert Jean Le Rond, eds., Encyclopédie ou Dictionnaire raisonné des sciences, des arts et des métiers, 1751-1765, Vol. 13, 375a-376b.

Weart, Spencer R., 1992. The Solid Community In: Lilian Hoddeson, Ernest Braun, Jürgen Teichman and Spencer Weart, eds., Out of the Crystal Maze. Chapters from the History of Solid State Physics. Oxford/New York: Oxford University Press, 617-666.

\section{Bernadette Bensaude-Vincent}

UFR de philosophie

Université Paris 1

17 rue de la Sorbonne

75230 Paris, Cedex 05

France

E-Mail: bensaude@club-internet.fr 